\title{
Misbehaving Toddler or Moody Teenager: Examining the Maturity of the Field of K-12 Online Learning
}

\section{Niños o adolescentes con mal comportamiento: Examinando la madurez del campo del aprendizaje en línea K-12}

\author{
Michael K. Barbour \\ Touro University California. Vallejo. California, USA \\ mkbarbour@gmail.com
}

\begin{abstract}
Depending on the reference, the practice of K-12 online learning began sometime between 1991 and 1996. Yet almost three decades later, there is still little research to describe the K12 online learning student experience, which has resulted in a lack of understanding of the actual instructional model, nature of the curriculum, and type and amount of support employed by K-12 online learning programs. Further, much of the available research is atheoretical, methodologically questionable, contextually limited, and overgeneralized. All these factors make the K-12 online learning research that does exist of little value in guiding practice. This manuscript examines the maturity of research in the field of K-12 online learning, with the goal of providing researchers with meaningful impact on future practice. Keywords: Misbehaving Toddler, Moody Teenager, K-12, Online Learning
\end{abstract}

\section{Resumen:}

Dependiendo de la referencia, la práctica del aprendizaje en línea de K-12 comenzó en algún momento entre 1991 y 1996. Sin embargo, casi tres décadas después, todavía hay poca investigación para describir la experiencia de los estudiantes de aprendizaje en línea de K12, que ha resultado en una falta de comprensión del modelo de instrucción real, la naturaleza del plan de estudios y el tipo y la cantidad de apoyo empleado por los programas de aprendizaje en línea K-12. Además, gran parte de la investigación disponible es teórica, metodológicamente cuestionable, contextualmente limitada y sobregeneralizada. Todos estos factores hacen que la investigación de aprendizaje en línea K-12 que existe sea de poco valor para guiar la práctica. Este manuscrito examina la madurez de la investigación en el campo del aprendizaje en línea en K-12, con el objetivo de proporcionar a los investigadores un impacto significativo en la práctica futura.

Palabras clave: Niño con mal comportamiento, Adolescente con mal comportamiento, K12, Aprendizaje en línea.

As a part of their Online Learning Definitions Project, the International Association for K-12 Online Learning (iNACOL) (2011), defined online learning as: 
education in which instruction and content are delivered primarily over the Internet. The term does not include print-based correspondence education, broadcast television or radio, videocassettes, and stand-alone educational software programs that do not have a significant Internet-based instructional component. Used interchangeably with virtual learning, cyber learning, e-learning. (p. 7)

iNACOL has historically been the dominant professional association in the United States for practitioners of K-12 distance, online, and blended learning.

While it is important to acknowledge that distance learning has occurred within the K-12 environment for over a century (Clark, 2003, 2007, 2013), the first documented instance of K-12 online learning was a program developed around 1991 by Laurel Springs School, a private school in California (Barbour, 2011). According to Clark (2003), one of the first public schools to begin offering K-12 online learning was the Utah Electronic High School around 1993 (although most courses were still offered in a correspondence format). Darrow (2010) reported that a year later the first full-time cyber charter school was established in California. The first supplemental virtual schools began around 1997 (Friend \& Johnston, 2005; Pape, Adams, \& Ribeiro, 2005). Regardless of which of these events is considered the "start" of the practice of K12 online learning, it is safe to assume that the use of K-12 online has been occurring for 23 to 29 years - or approximately two to three decades.

From a research perspective, the first major review of the literature related to K-12 distance and online learning was Rice (2006). However, the first review of the literature to focus solely on K-12 online learning was Barbour and Reeves (2009). The first Handbook on Research in K-12 Online and Blended Learning was published in 2014, with a second edition published three years later (Ferdig \& Kennedy, 2014; Kennedy \& Ferdig, 2017). While there had been a variety of special issues focused on K-12 online learning in other journals, it wasn't until 2015 that a journal specifically focused on the field of K-12 online and blended learning was established (i.e., the Journal of Online Learning Research). As iNACOL began to shift their focus away from K-12 online and blended learning towards personalized learning and competency-based education, the Digital Learning Collaborative - with their Digital Learning Annual Conference - was created in 2018 as a professional association for both practitioners and scholar.

Even with these developments in the scholarship of K-12 online learning, like many newer fields, the practice has outpaced the availability of useful research. This is particularly true in areas where technology is a significant factor in the practice of the field. However, as we approach the conclusion of three decades of practice, it is worthwhile to begin to reflect on how mature is the scholarship within the field of K-12 online learning? This article aims to address this question in a systematic fashion. ${ }^{1}$

\footnotetext{
${ }^{1}$ With permission, this article updates and expands themes that were first developed in Barbour (2018a) and Molnar et al. (2019).
}

Misbehaving Toddler or Moody Teenager: Examining the Maturity of the Field of K-12 Online Learning. Michael K. Barbour. 


\section{Maturity of the Field}

In order to measure the maturity of the field of K-12 online learning a structure to accomplish the task must be outlined. Graham, Henrie, and Gibbons (2014) believed that, "wellestablished scholarly domains have common terminology and widely accepted models and theories that guide inquiry and practice, while researchers in less mature domains struggle to define terms and establish relevant models" (p. 13). However, it was Saba (2013), in his discussion of the state of the broader field of distance education, who outlined four specific challenges that face a field as it matures: (1) confusing terminology, (2) a lack of historical perspective, (3) the absence of construct validity, and (4) a postmodern turn. In this section, we will examine the state of research into K-12 and online learning through the lens of these four challenges; as well as an examination of the American-centrism of the field.

\section{Confusing Terminology}

In his seminal work The Structure of Scientific Revolutions, Kuhn (1970) argued that the distinctness of a particular field is reflected in the shared paradigms or understandings of the research community. One such paradigm is the establishment of unique and recognized definitions, which is also often seen as a sign of the maturity of a given field (Januszewski \& Molenda, 2008). Saba (2013) wrote one of the limitations of the field of distance education in general was "the emergence of terms and phrases in the current literature that have received acceptance among different groups of practitioners, while they remain poorly defined, or undefined" (p. 49). The same can be said of the field of K-12 online learning.

In the opening paragraphs of this article, the field has been referred to as (a) K-12 online learning, (b) K-12 distance and online learning, and (c) K-12 online and blended learning. The official definitions project from the traditional practitioner association in the field even stated that these terms could be and were used interchangeably with terms like virtual learning, cyber learning, e-learning, and hybrid learning. In fact, to further complicate the terminology, iNACOL's Online Learning Definitions Project defined cyber school as "a formally constituted organization (public, private, state, charter, etc.) that offers full-time education delivered primarily over the Internet; term used synonymously with the terms 'virtual school,' 'eSchool,' and 'online school"' (iNACOL, 2011, p. 5). Similarly, the entries for eSchool and online school use the exact same definition, while the entry for virtual school simply says "see online school."

It is this kind of poorly defined terminology that allowed the authors of the annual Keeping Pace with K-12 Digital Learning reports to claim that "research from K-12 online and blended courses and schools have provided over a decade's worth of evidence to suggest that teaching and learning online can work" (Watson \& Murrin, 2014, p. 15). This claim was supported with selective literature focused on part-time or supplemental K-12 online learning

Misbehaving Toddler or Moody Teenager: Examining the Maturity of the Field of K-12 Online Learning. Michael K. Barbour. 
programs, ignoring the well established understanding that "the effectiveness of [part-time K-12] distance education appears to have more to do with who is teaching, who is learning, and how that learning is accomplished, and less to do with the medium" (Rice, 2006, p. 440). The claim also ignores the fact that:

whether the format of the research was academic, independent state audit, or investigative journalist's report, the main theme from this body of work is that in a full-time virtual school setting, student performance is considerably poorer than the performance of students in a face-to-face learning environment. (Molnar et al., 2017, p. 46)

A reality that has been repeatedly represented in the National Education Policy Center's annual Virtual Schooling in the United States reports (Miron \& Gulosino, 2016; Miron, Shank, \& Davidson, 2018; Miron \& Urschel, 2012; Molnar et al. 2013; 2014; 2015; 2017; 2019). These documents, as well as the other literature related to the effectiveness of full-time K-12 online learning, were summarized by Barbour, Mann, and Melchoir (2018).

For the most part, academic authors have used the term K-12 online learning to refer to the general field (Barbour, 2019). Similarly, within the academic literature the term virtual school is generally used when referring to supplemental forms of K-12 online learning (i.e., where students are enrolled in a brick-and-mortar school, but take one or more courses online to supplement their studies). The term cyber school is generally used when referring to full-time forms of K-12 online learning (i.e., where students are engaged in full-time online instruction and do not attend a brick-and-mortar school at all). However, these general conventions are not used consistently in the academic literature. For example, much of the early literature in the field used the term virtual school as a way to describe the general field of K-12 online learning (Molnar et al. 2013). Further, many scholars adopt the term in the legislation or policy in the jurisdiction where they are conducting the research. For example, policy in Pennsylvania uses the term cyber charter school and much of the research published on that state also uses that term (e.g., Ahn, 2011; Ellis, 2008; Mann, Kotok, Frankenberg, Fuller, \& Schafft, 2016). In many states full-time online schools are referred to as virtual charter schools in legislation, and researchers working in those states will often use that term to describe a full-time cyber school (Klein \& Poplin, 2008; Torre, 2013). Finally, as much of what is known about the K-12 online learning has come from non-academic organizations, various government agencies, and even the popular media, it is important to note that authors are also inconsistent in how they use the terms online learning, virtual schooling, cyber schooling, or derivatives thereof-often using them interchangeably as synonyms.

But the same can be said of literature in formal academic publishing outlets as well. In the final, regular issue of $J O L R$ for $2019,{ }^{2}$ there is an article that reports on a case study of a "full-time virtual school" (Rice, Oritz, Curry, \& Petropoulos, 2019). In their description of the article, the editors write:

\footnotetext{
${ }^{2}$ See https://www.learntechlib.org/primary/j/JOLR/v/5/n/2/ for the table of contents
}

Misbehaving Toddler or Moody Teenager: Examining the Maturity of the Field of K-12 Online Learning. Michael K. Barbour. 
Rice, Ortiz, Curry, and Petropoulos authored the second article in this issue, "A Case Study of an Adoptive Foster Parent Working to Support a Child with Multiple Disabilities in a Full-Time Virtual School." This article is especially interesting because it addresses several topics needing attention from researchers - students with disabilities, parental engagement, and cyber charter schools. The goal of this research is not to provide generalizable findings. Instead, by focusing only on one parent, the article provides a rich description of the parent's experiences and perceptions while her foster son was enrolled in a cyber school. (Borup \& Archambault, 2019, p. 120 - emphasis added).

The next article in this issue was a case study that was focused on a "nonprofit online educational program" (Turley \& Graham, 2019). The final article in this issue was a study focused on data from "an accredited state-wide virtual school" (Bae Kwon, DeBruler, \& Kennedy, 2019). Three articles from the same issue of a journal that is specifically focused on the field of K-12 online learning. Two articles describing their focus as being on some type of virtual schools. One article where the author used one descriptive term and the editors used another descriptive term (two others in fact). One article that included a description that has yet to be used in this article. The lack of consistency in the terminology makes these comparisons difficult for policymakers, practitioners, and the general public to understand the nuances of the field and make meaningful comparisons. These individuals, most of whom are outside of or new to the field, would have difficulty knowing if the two articles focused on virtual schools were researching similar programs. Those same individuals who also not be aware that the "nonprofit online educational program" and the "accredited state-wide virtual school" had a lot more in common than the "full-time virtual school" had with the "accredited state-wide virtual school."

\section{Lack of Historical Perspective}

In his examination of the maturity of a discipline, Bedeian (2004) argued that it was a function of the maturity of a particular field - and those in it - that it could recall its own history. As was referenced earlier, in the preface to the first edition of the Handbook of Research on K-12 Online and Blended Learning, the editors wrote "although most of the people doing work in the area knew each other (and even occasionally worked together), many new to the field thought that they were discovering K-12 online and blended instruction for the first time" (Ferdig \& Kennedy, 2014, p. vii). The editors continued by underscoring the rationale for the handbook by stating:

this wasn't an egotistical exercise: this wasn't another occasion where one academic was calling out peers for not including their citation or reference in a paper. Rather, this was a problem as researchers - particularly those new to the field seemed to be lacking the opportunity to proverbially 'stand on the shoulders of giants.' (p. vii)

Misbehaving Toddler or Moody Teenager: Examining the Maturity of the Field of K-12 Online Learning. Michael K. Barbour. 
While he was speaking about the broader field of distance education, Saba (2013) summarized this problem when he lamented that "reading some of the articles, even in peer reviewed journals, one comes to the inevitable conclusion that their authors, editors, and reviewers are not familiar with the historical origin and conceptual growth of the field" (p. 50).

A good measure of this lack of familiarity with the historical origin and conceptual growth of the field is best illustrated by looking at dissertations produced by those who should represent the next generation of researchers in the field. Arnesen, Hveem, Short, West, and Barbour (2019) recently conducted an analysis of all of the journal articles that they were able to identify related to K-12 online learning. Based on thorough data collection, Arnesen and her colleagues identified 356 different journal articles, and the most prolific journal article authors (see Table 1).

Table 1.

List of authors by number of journal articles based on Google Scholar and Scopus

\begin{tabular}{|c|c|c|c|c|}
\hline \multicolumn{2}{|r|}{ Google Scholar } & \multirow[b]{2}{*}{ Rank } & \multicolumn{2}{|l|}{ Scopus } \\
\hline $\begin{array}{l}\text { \# of } \\
\text { Articles }\end{array}$ & Author & & Author & $\begin{array}{l}\text { \# of } \\
\text { Articles }\end{array}$ \\
\hline 57 & Michael Barbour & 1 & Michael Barbour & 11 \\
\hline 19 & Cathy Cavanaugh & 2 & Elizabeth Murphy & 8 \\
\hline 18 & Ken Stevens & 3 & Charles Graham & 7 \\
\hline 16 & Elizabeth Murphy & 4 & Jered Borup & 6 \\
\hline 15 & Charles Graham & 5 & Cathy Cavanaugh & 6 \\
\hline 14 & Margaret Roblyer & 6 & Maria Rodiguez-Manzanares & 6 \\
\hline 14 & Jered Borup & 7 & Dennis Beck & 4 \\
\hline 12 & Leanna Archambault & 8 & Erik Black & 4 \\
\hline 11 & Diana Greer & 9 & Margaret Roblyer & 3 \\
\hline 10 & Dennis Beck & 10 & Meredith DiPietro & 3 \\
\hline 10 & Niki Davis & 11 & Randall Davis & 3 \\
\hline
\end{tabular}

These lists represent 15 unique scholars in the field of K-12 online learning. During the 2019 publishing cycle, the Journal of Online Learning Research published three issues and a total of 13 articles. Table 2 examines number of articles that cited any of these 15 scholars.

Table 2.

Citations of top authors by articles published in the Journal of Online Learning Research in 2019

\begin{tabular}{|l|c|c|c|c|}
\hline Scholar & $\begin{array}{c}\text { Number of Articles } \\
\text { Cited In }(\mathrm{n}=13)\end{array}$ & $\begin{array}{c}\text { Number of } \\
\text { Times Cited }\end{array}$ & $\begin{array}{c}\text { Google Scholar } \\
\text { Rank }\end{array}$ & $\begin{array}{c}\text { Scopus } \\
\text { Rank }\end{array}$ \\
\hline Charles Graham & 7 & 21 & 5 & 3 \\
\hline Michael Barbour & 6 & 22 & 1 & 1 \\
\hline
\end{tabular}

Misbehaving Toddler or Moody Teenager: Examining the Maturity of the Field of K-12 Online Learning. Michael K. Barbour. 
RED. Revista de Educación a Distancia. Núm. 64, Vol. 20. Artíc. 4, 30-09-2020

DOI: http://dx.doi.org/10.6018/red.412821

\begin{tabular}{|l|c|c|c|c|}
\hline Jered Borup & 5 & 14 & 7 & 4 \\
\hline Cathy Cavanaugh & 5 & 8 & 2 & 5 \\
\hline Leanna Archambault & 5 & 8 & 8 & - \\
\hline Margaret Roblyer & 2 & 2 & 6 & 9 \\
\hline Ken Stevens & 1 & 1 & 3 & - \\
\hline Elizabeth Murphy & 1 & 1 & 4 & 2 \\
\hline Diana Greer & 1 & 1 & 9 & - \\
\hline Dennis Beck & 1 & 1 & 10 & 7 \\
\hline Maria Rodiguez-Manzanares & 1 & 1 & - & 6 \\
\hline Erik Black & 1 & 1 & - & 8 \\
\hline Niki Davis & 0 & 0 & 11 & - \\
\hline Meredith DiPietro & 0 & 0 & - & 10 \\
\hline Randall Davis & 0 & 0 & - & 11 \\
\hline
\end{tabular}

First, this is by no means a systematic or comprehensive sampling of this particular journal, nor is it necessarily representative of the field as a whole (both of in terms of the most influential scholars or in terms of recent published scholarship). However, it does provide a cursory analysis of the scholars published by a top journal in the field, specifically focused on K-12 online learning, over the past calendar year. Interestingly, there were three scholars that were not cited a single time. Additionally, two of the 13 articles that were published did not cite a single one of these scholars, while three articles only cited a single scholar and four articles cited two of these scholars. This result means that nine of the 13 articles cited two or fewer of the top 15 scholars as identified Arnesen et al.'s (2019) sample of 356 articles.

While a more systematic effort of this type of analysis is in order, this illustration does highlight the fact that articles published in this journal over the past year appear to exhibit a lack of familiarity with the historical origin and conceptual growth of the field of K-12 online learning. In their handbook preface, Ferdig and Kennedy (2014) actually commented on this very issue:

There is no clear reason why this happens. Perhaps it has to do with the fact that people in the field publish in a wide variety of journals. Articles in K-12 online and blended instructional might appear in anything from the Journal of Technology and Teacher Education to The International Review of Research in Open and Distance Education and from the Journal of Medical Internet Research to The Internet and Higher Education. (p. vii)

This is quite accurate, as Arnesen et al. (2019) found that their sample of 356 articles came from 155 different journals, and there were 102 different journals that only published a single article. This cursory analysis is also not intended to single out the Journal of Online Learning Research or its editors. In fact, if one were to examine the 356 journal articles in the sample provided by

Misbehaving Toddler or Moody Teenager: Examining the Maturity of the Field of K-12 Online Learning. Michael K. Barbour. 
Arnesen and her colleagues, ${ }^{3}$ they would discover that there were a total of 10 articles published in 2015 or earlier that had never been cited and 53 articles published in 2015 or earlier that had been cited fewer than five times. ${ }^{4}$ Many of these 63 articles were authored by some of the top authors listed in Table 1, published in journals that featured multiple K-12 online learning articles, and written on topics that were relevant to the field. Hence, there should be no apparent reason why many of these articles have not been cited in subsequent research.

It should be noted that the analysis of the historical perspective of the field above has been limited to journal articles within the field. Yet, as was discussed earlier, numerous scholars have described how the amount of K-12 online learning research available in journals was limited. For example, Barbour and Reeves (2009) stated that, "much of the literature for virtual schooling has primarily been disseminated through private re-search centers, evaluations or doctoral dissertations" (p. 403). This additional fragmentation of where the scholarship of K-12 online learning is published further complicates scholars' ability to situate their own research within the historical origin and conceptual growth of the field.

Another reason for the lack of historical perspective may be explained by Saba (2007) when he wrote:

For some, history starts when they become interested in the field. Depending on the initial period of their focus, some authors attempt to reduce the entire field of distance education to a narrow view defined by a particular medium of communication (e.g., webbased learning) or mode of information transmission (e.g., online learning). This reductionist approach to understanding the field is in sharp contrast to the holistic systems approach that is essential for developing a comprehensive theory of the field. (p. 50)

Each of these issues is a problem within the field of K-12 online learning. For example, the oldest article in the sample of K-12 online learning journal articles used by Arnesen et al. (2019) was from 1997. However, Lowes (2004) examined what she described as "the research methods used during the first 10 years of research on online teaching and learning" in her chapter in the International Handbook on K-12 Online and Blended Learning (p. 83). Interestingly, the first 10 years according to Lowes spanned a period of 2004 to 2014.

In the next edition of that same handbook, Lokey-Vega, Jorrín-Abellán, and Pourreau (2018) used research deposited into the Research Clearinghouse for K-12 Blended and Online Learning to examine the use of theory in the field of K-12 online and blended learning. The clearinghouse ${ }^{5}$ only included 13 items prior to the year 2000 - only five of which were focused on K-12 distance, online, and/or blended learning (suggesting that their sample began in 1997,

\footnotetext{
${ }^{3}$ The complete data set of the 356 articles used by Arnesen and her colleagues is available for download at https://tinyurl.com/K12OnlineLearningData

${ }^{4}$ See Arnesen, Walters, Barbour, \& Borup (2020) for an analysis of these uncited and low cited articles.

${ }^{5}$ The Research Clearinghouse for K-12 Blended and Online Learning is available at https://k12onlineresearch.org/ and is described as "a repository of references to research articles and other publications from the field of K-12 online and blended learning."
}

Misbehaving Toddler or Moody Teenager: Examining the Maturity of the Field of K-12 Online Learning. Michael K. Barbour. 
but contains an extremely limited pre-2000 sample). However, as was described in the opening paragraphs, the history of the field of K-12 online learning began as early as 1991. So an examination of the field that began in 1997 or 2004 could easily have excluded seminal research in the field. It should also be noted that earlier history also ignored other forms of K-12 distance learning, such as instructional film around 1910, educational radio in 1921, correspondence education around 1923, educational television programming in the 1930s, educational satellites in the 1960s, and audiographics or telematics in the 1980s (Clark, 2007) (this is an issue that will be discussed in greater detail in subsequent sections). This timeline is also evidence that by beginning their examination of the field to the 1990s or 2000s, these authors were also focusing on a single medium of $\mathrm{K}-12$ distance education.

To date, there have been a total of four journal articles that can be described as major reviews of literature in the field. The first of these literature reviews was written by Rice (2006), and focused broadly on literature related to K-12 distance education. However, the next two literature reviews (i.e., the ones written by Barbour and Reeves [2009] and by Cavanaugh, Barbour, and Clark [2009]) were focused only on K-12 online learning, whereas the final literature review written by Hasler Waters, Barbour, and Menchaca (2014) focused solely on full-time K-12 online learning.

The reality of the field of K-12 online learning is that scholars have published their research in a variety of outlets-some academic and some more mainstream. This pattern has created a situation where it becomes much more difficult to find relevant literature to support a scholar's current study. However, even in instances where scholars or publishing outlets are clearly known, too often are those sources excluded when scholars attempt to build on the knowledge in the field. When this reality is coupled by the fact that too many scholars reduces their definition of the field to simply K-12 online learning, it implies that the empirically-based lessons learned and the conceptual models that helped explained these K-12 distance learning environments have no relevance for the 'medium of the day.'

\section{Absence of Construct Validity}

In the third edition of the Handbook of Research on Educational Communications and Technology, Spector (2008) wrote:

The basic question that research aims to answer is why things happen the way they do. Developing an answer to such a question often involves a general rule or principle that has explanatory power that will be predictive. ... A related set of rules and principles that has been shown to be reliable in many situations might be regarded as theory. (p. 22) Essentially, if research is robust, valid, and replicated enough times, than it should be able to develop theories that explain why things happen the way that they do. In order for an explanation to be robust, valid, and replicated enough times, it must have a consistent form of measurement. Construct validity is "the degree to which a test measures what it claims, or

Misbehaving Toddler or Moody Teenager: Examining the Maturity of the Field of K-12 Online Learning. Michael K. Barbour. 
purports, to be measuring" (Brown, 1996, p. 231), or more simply, has the instrument been used in enough studies so those in the field can be confident that it is valid?

Unfortunately, there has been an absence of the construction and validation of instruments in the field of K-12 online learning (or instruments that possess construct validity). To date, there has only been a single systematic effort to create a validated instrument- the Educational Success Prediction Instrument (ESPRI) (Roblyer, 2005; 2006; Roblyer \& Davis, 2008; Roblyer, Davis, Mills, Marshall, \& Pape, 2008; Roblyer \& Marshall, 2002-2003). Additionally, beyond these initial validation studies conducted by Roblyer and her colleagues, there has only been limited use of the instrument in others research (e.g., Siko, 2014; Sparks, 2017). In his review of the use of validated tools in the field of K-12 online learning, Barbour (2018a) also referenced the use of a validated instrument based on the Parental Involvement Mechanisms Model in a single study by Liu, Black, Algina, Cavanaugh, and Dawson (2010). The use of validated instruments in the field is important. According to Cronbach and Meehl (1955), "construct validation is involved whenever a test is to be interpreted as a measure of some attribute or quality, which is not "operationally defined." The problem faced by the investigator is, "What constructs account for variance in test performance?"” (p. 282). Basically, how do we know this variable is causing this outcome and, more importantly, how much of this outcome is being caused by this variable. Further, without validated tools, there is no guarantee the instruments that researchers design for each and every piece of research they engage in is actually measuring what it is designed to measure or how well the instrument reflects the reality of the research setting (Barbour, 2018a). Validated instruments are the building blocks for models that can explain specific situations within the K-12 online learning context. "Models ... are intended for building a theory of distance education that is inspired by current knowledge, research, and practice. They may be adopted by practitioners to guide program development, implementation, and evaluation" (Saba, 2007, p. 52). Without validated instruments, there is little confidence that research can really be trusted. If research cannot be trusted, K-12 teachers have good reasons to question whether that research can guide their own online classroom practices (Geelan, 2006).

The lack of validated instruments in the field has also resulted in a lack of theory development or theoretical underpinnings within the research in the field. As Saba (2013) explained, "for inclusion of these concepts in a theory of distance education, at the minimum, such constructs must be validated in experimental empirical studies" (p. 50). Further, Lincoln and Lynham (2011) argued that theory is of particular importance to the informed practice, continual improvement, and maturity of a field. Without the use of validated instruments, there has been a general lack of theory development in the field.

To date, one of the few lines of inquiry that has attempted to ground itself with a theoretical or conceptual framework is the work of Borup and his colleagues (Borup, 2016a, 2016b; Borup, Graham, \& Drysdale, 2014; Borup \& Stevens, 2016; Borup, Stevens, \& Hasler Waters, 2015). The Adolescent Community of Engagement (ACE)

Misbehaving Toddler or Moody Teenager: Examining the Maturity of the Field of K-12 Online Learning. Michael K. Barbour. 
framework was introduced by Borup, West, Graham, and Davies (2014) as a way to describe the nature of engagement that occurs in an online learning course by examining the variables of student engagement, teacher engagement, peer engagement, and parent engagement. Borup and his colleagues have used this framework to specifically examine the parent engagement aspect of the ACE framework at a specific cyber charter school. (Barbour, 2018a, p. 11)

Barbour also reported that Dikkers and Whiteside had made use of social presence theory, which examines the ability of participants in technology-mediated communication to send and receive social cues, in their own work (see Dikkers, Whiteside, \& Lewis, 2013; Whiteside \& Dikkers, 2012).

One of the most comprehensive efforts to explore the use of theory by researchers in the field was undertaken by Lokey-Vega et al. (2018). These authors examined the titles, keywords, and abstracts of all 790 unique publications in the Research Clearinghouse for K-12 Blended and Online Learning for any reference to theory. The authors acknowledged that the clearinghouse was not a comprehensive resource, but was the broadest single collection of K-12 online and blended learning literature available at the time. They also noted that not every entry had an abstract or keywords. The authors reported that 137 references or $17 \%$ contained one of the 26 different theoretical terms that had been identified in the research. Although many would argue that several of the "theoretical terms" were not actual theories. For example, the 26 theoretical terms included - among others - five studies that utilized learning styles, a discredited theory (Coffield, Moseley, Hall, \& Ecclestone, 2004; Scott, 2010). Additionally many would argue that "theoretical terms" such as personalized learning, collaborative learning, metacognition, participatory learning, and theory of online learning were not actual theories. Regardless, Lokey-Vega et al. (2018) concluded, "the work has just begun as we stretch our field to seek and understand instances of success and test well-supported historically-important distance learning theories, such that we can build a body of best-practice literature founded on theory" (p. 85).

Given the near complete lack of validated instruments, coupled with the rare utilization of models, frameworks, or theories to guide researchers, the scholarship in the field of K-12 online learning can be described as largely atheoretical. With few validated instruments, researchers are also unable to even begin the process of developing and testing the necessary frameworks to create theories that might become predictive models for the practice of K-12 online learning. However, if theory could be developed or validated instruments used, "such a body of literature would go beyond serving researchers; but most importantly, it would play a socially responsible role in impacting the problems facing teachers and children in K-12 online learning contexts" (Lokey-Vega et al., 2018, p.85).

\section{Postmodern Turn}

Misbehaving Toddler or Moody Teenager: Examining the Maturity of the Field of K-12 Online Learning. Michael K. Barbour. 
The postmodern turn in the broader field of distance education can be seen as a summary, or natural conclusion, of the three previous discussions. In describing the issue of postmodernism, Saba (2013) wrote:

European postmodernism tends to search for the different in a seemingly endless process of deconstructing tenets of established disciplines.... when a discipline is fragmented in this way, the question becomes: is there an approach to bringing seemingly unrelated concepts into a coherent picture and presenting them in a form that would make sense to the novice and the expert alike? (emphasis in original, p. 51)

When the work of the traditional professional association for practitioners of K-12 online and blended learning is devoted to personalized learning and competency-based education (refer to the "Our Work" section of the International Association for K-12 Online Learning website at https://www.inacol.org/our-work/), this is an excellent illustration of the fragmentation of the field. The fact that K-12 online learning, virtual schooling, and cyber schooling are taken within much of the academic literature to refer to three different types of education.

Another example of the fragmentation that exists within the research base of both K-12 distance and online learning can also be seen in the lack of historical understanding. For example, in the fourth edition of the Handbook of Distance Education, Barbour (2019) began his chapter on K-12 online learning with the following history lesson:

The first documented use of K-12 distance learning in the United States was the use of instructional film around 1910 (Saettler, 2004). This initial distance medium was followed by the use of correspondence education in a program Nebraska around 1923 (Broady, Platt, \& Bell, 1931), and the use of educational radio through the Ohio School of the Air in 1921 (Saettler, 2004). While some educational radio programs continued to serve K-12 distance education students for some time, such as the Wisconsin School of the Air (Bianchi, 2002); as technology evolved, so did the medium for K-12 distance education. For example, Bramble (1988) described the use of an educational telephone system as the basis for the Learn Alaska Network. During the1930s there were several instances of educational television programming (Kurtz, 1959), although according to Clark (2000) it was rare for programs using this medium to offer full courses. In the 1960s, the use of educational satellites emerged as another generation of technology used for the delivery of K-12 distance learning (Jajkowski, 2004), which was used by programs in a variety of states to serve primarily rural areas (Howley \& Harmon, 2000; Kirby, 1998; Pease \& Tinsley, 1986). Beginning in the 1980s, audiographics or telematics networks began to be developed by several states, such as Iowa, Maine, and Utah (Hezel Associates, 1998). (p. 522)

However, it is almost universal that research and literature in the field of K-12 online learning ignores the scholarship over the past century related to these legacy forms of K-12 distance education.

Misbehaving Toddler or Moody Teenager: Examining the Maturity of the Field of K-12 Online Learning. Michael K. Barbour. 
Saba (2013) continued his description of postmodernism by stating that "the core of [the American postmodern approach... was the idea of webs of relationships among different or even ostensibly unrelated concepts, what we would call a systems approach" (p. 51). Essentially Saba is referring to the use of theoretical perspectives to explain or predict how some aspect of K-12 online learning will work. The inability of researchers to utilize models, frameworks, or and theories guide their scholarship - as was described in the previous section - is also evidence that the field is deficient based on this American postmodern perspective.

Regardless if the examination is through the lens of the European perspective of postmodernism or the American perspective of postmodernism, in both instances the field of K12 online learning is found lacking. From the European point of view, the field has fallen into the trap of fragmentation that limits the overall understanding within the field and prevents the field from building upon its historical base. From the American point of view, the field does not have the basic building blocks (e.g., validated instruments, models/frameworks, theories, etc.) to create the explanatory systems that might help us understand the relationship between different aspects of K-12 online learning.

\section{American-Centrism}

While not one of the four challenges described by Saba (i.e., confusing terminology, a lack of historical perspective, the absence of construct validity, and a postmodern turn), there is a fifth challenge that the field of K-12 online learning must overcome-geographic focus. For example, in his chapter in the second edition of the Handbook of Research on K-12 Online and Blended Learning, Barbour (2018b) concluded that:

the reality is that the vast majority of the scholarship that is being published focuses on the United States (and to a lesser extent North America), even though there is a great deal of K-12 online and blended learning occurring outside of the United States. (p. 23) As a part of this chapter, Barbour analyzed the Journal of Online Learning Research and found that the vast majority of articles that had been published focused on the United States. Similarly, Barbour (2011) analyzed K-12 online learning scholarship in major distance education journals and reported that over half of the K-12-focused articles were based on the United States. Both of these findings were consistent with $\mathrm{Hu}$, Arnesen, Barbour, and Leary (2019), who analyzed all 51 articles published in the Journal of Online Learning Research from 2015 to 2018. They reported that excluding the "five articles that had no specific geographic focus or we were unable to determine the location... the vast majority (i.e., 91\%) of articles with a geographic focus published by [the journal] focused on the United States" (p. 132). In describing the article in their editorial, Borup and Archambault (2019) acknowledge that they viewed the "finding as an opportunity to better focus on international research and [they had] launched the international section in the last issue" (p. 120). Although they also noted that "while the current issue does not include an article for the international section, [they] strongly encourage submissions from

Misbehaving Toddler or Moody Teenager: Examining the Maturity of the Field of K-12 Online Learning. Michael K. Barbour. 
contexts beyond the United States" (p. 120). In the four issues published since the international section was introduced, only two issues included any articles in that section (and both of those issues only included a single article in the international section — see Cavanaugh \& Roe [2019]; Seok \& DaCosta [2020]).

In this introduction to the new "International Section" of the second edition of the Handbook of Research on K-12 Online and Blended Learning, Barbour (2018c) listed a series of studies from Canada, New Zealand, South Korea, and Australia that he claimed scholars should be familiar with. He also list a series of countries that were the focus of individual case studies from the recent book Online and Distance Education in Schools: Global Perspectives on Policy and Practice edited by Clark and Barbour (2015). A year prior, Barbour and Kennedy (2014) described various K-12 online learning programs that exists in the three North America countries, along with Australia, New Zealand, Singapore, South Korea, and Turkey. However, the fact that scholars in the field are able to list the isolated instances of research focused on jurisdictions outside of the United States underscored the American-centrism of the field of K-12 online learning.

\section{Conclusions and Recommendations}

As a part of the first edition of the Handbook of Research on Educational Communications and Technology, Holloway (1989) wrote one of the closing chapters where he summarized and critiqued the types of designs that had been used by researchers in the field, where he suggested that, "there [were] excellent studies, but they [were] limited by short time spans ... the entire corpus of research in diffusion and adaption of educational technology seems less rigorous in technique and design and weak in causal findings" (p. 1129). While Holloway was broadly referencing the field of educational technology, it was also quite descriptive for the field of distance education. Black (2007) wrote, "although isolated studies ... were undertaken in the early decades of the last century, scholarship in the sense of a sustained, growing body of knowledge generating theory through systematic research, really began in the 1950s" (p. 3).

What can be said specifically of K-12 online learning? Barbour (2019) argued that: beyond the body of comparative research, much of the research has been qualitative in nature (which can be quite useful for understanding K-12 distance and online learning in a specific setting, but by definition are not generalizable to other jurisdictions). Further, a significant portion of the body of research suffers rom issue of over reaching (e.g., interviewing a group of hand picked teachers or developers and using their opinions to generate "best practices"). (p. 534)

To illustrate this point, Barbour analyzed a study into the design of online courses from secondary students (Barbour, 2005; 2007) and a study into the practices of online teachers (DiPietro, Ferdig, Black, \& Preston, 2008). In both instances, Barbour (2019) described how the researcher collected perception-based data from a single source, a small sample, and a specific geographic focus; with no verification of the opinions being expressed by those surveyed or

Misbehaving Toddler or Moody Teenager: Examining the Maturity of the Field of K-12 Online Learning. Michael K. Barbour. 
interviewed. Ironically, both studies intended to report on principles and best practices for the field as a whole.

While most studies are not as methodologically limited, and do not overreach to the same extent as the examples above, the majority of research into teaching and learning within the K-12 online environment have been studies of particular cases (Lowes \& Lin, 2018). "As needed and important as these [exploratory] studies are, their results are seldom subjected to experimental data-based research for determining the validity of newly surfaces constructs beyond their initial exploration" (Saba, 2013, p. 51).

In the conclusion to his chapter on the state of research and theory development in the field of distance education in the first edition of the Handbook on Distance Education, Saba (2003) wrote:

If distance education is to be the educational paradigm, distance education theory must explain the whole of education and not only when teacher and learning are separated in space and time. Such separation can be bridged by communication technology, a fact demonstrated by teachers and students everywhere. But if students and teachers are separated by the total absence of dialogue, as occurs in many classrooms across the country and around the world, bringing them together until they stand nose to nose will not offer a solution. (p. 17)

The same can be said of K-12 online learning. It does not matter if the student is separated by time, place, path, and/or pace from their teacher or other students. As long as the appropriate conditions for learning are present, learning will occur. The goal for researchers is to discover what those conditions are, and then for teachers to incorporate them into their practices and policymakers to enact them into their regulations.

Based upon what is known about K-12 online learning from the research, there are five recommendations for researchers. As the general terminology used to describe various aspects of the field is often confounded, researchers should seek to define their specific focus of inquiry in each research study. Researchers need to understand that research associated with other forms of distance education; as well as the research into online learning with other populations; has lessons to offer the research and practice of K-12 online learning. Researchers should borrow instruments that have been validated in studies within the broader field of distance education and apply those instruments to K-12 populations, possibly re-validating these instruments for K-12 learners. Researchers also need to ground their studies in established theoretical and conceptual frameworks, which may provide opportunities to use existing validated instruments. Researchers need to view the field of K-12 online learning as related fields that are a part of the larger fields of K-12 distance education and distance education in general. With this expanded perspective, researchers need to be aware of the relevant research in these broader fields. Researchers need to seek opportunities to published research in international publication outlets, as well as consume research focused on K-12 online learning programs in international contexts. As the research in the field of K-12 online learning continues to mature, researchers need to ensure that their

Misbehaving Toddler or Moody Teenager: Examining the Maturity of the Field of K-12 Online Learning. Michael K. Barbour. 
methodological techniques continue to become more sophisticated by incorporating these recommendations.

Presentación del manuscrito / Received: 25 de marzo de 2020

Fecha de aprobación / Accepted: 10 de agosto de 2020

Fecha de publicación / Published: 30 de septiembre de 2020

Barbour, M. K. (2020). Misbehaving Toddler or Moody Teenager: Examining the Maturity of the Field of K-12 Online Learning. RED. Revista Educación a Distancia, 20(64). http://dx.doi.org/10.6018/red.412821

\section{Funding}

This research has not received any specific grant from funding agencies in the public, commercial or non-profit sectors.

\section{References}

Ahn, J. (2011). Policy, technology, and practice in cyber charter schools: Framing the issues. Teachers College Record, 113(1), 1-26.

Arnesen, K. T., Hveem, J., Short, C. R., West, R., \& Barbour, M. K. (2019). K-12 online learning journal articles: Trends from two decades of scholarship. Distance Education, $40(1), 32-53$.

Arnesen, K., Walters, S., Barbour, M. K., \& Borup, J. (2020). Irrelevant, overlooked, or lost? Trends in 20 years of uncited and low cited K-12 online learning articles. Online Learning, 24(2), 187-206. Retrieved from https://olj.onlinelearningconsortium.org/index.php/olj/article/view/2080

Association for the Advancement of Computing in Education. (2018). Journal of Online Learning Research. Waynesville, NC: Author. Retrieved from https://www.learntechlib.org/primary/j/JOLR/

Bae Kwon, J., DeBruler, K. \& Kennedy, K. (2019). A snapshot of successful K-12 online learning: Focused on the 2015-16 academic year in Michigan. Journal of Online Learning Research, 5(2), 199-225. Retrieved from https://www.learntechlib.org/primary/p/196643/

Barbour, M. K. (2005). The design of web-based courses for secondary students. Journal of Distance Learning, 9(1), 27-36.

Misbehaving Toddler or Moody Teenager: Examining the Maturity of the Field of K-12 Online Learning. Michael K. Barbour. 
Barbour, M. K. (2007). Teacher and developer perceptions of effective web-based design for secondary school students. Journal of Distance Education, 21(3), 93-114. Retrieved from http://www.jofde.ca/index.php/jde/article/view/30

Barbour, M. K. (2011). The promise and the reality: Exploring virtual schooling in rural jurisdictions. Education in Rural Australia, 21(1), 1-20.

Barbour, M. K. (2018a). Examining online research in higher education: What can we replicate in K-12? Lansing, MI: Michigan Virtual University. Retrieved from https://mvlri.org/research/publications/examining-online-research-in-highereducationwhat-can-we-replicate-in-k-12/

Barbour, M. K. (2018b). A history of K-12 online learning worldwide. In K. Kennedy \& R.E. Ferdig (Eds.), Handbook of research on K-12 online and blended learning (2nd ed., pp. 21-40). Pittsburgh, PA: Educational Technology Center Press. Retrieved from https://figshare.com/articles/Handbook_of_Research_on_K12_Online_and_Blended_Learning_Second_Edition_/6686813

Barbour, M. K. (2018c). Part VIII. K-12 online learning around the world - Introduction. In K. Kennedy \& R.E. Ferdig (Eds.), Handbook of research on K-12 online and blended learning (2nd ed., pp. 595-600). Pittsburgh, PA: ETC Press. Retrieved from https://figshare.com/articles/Handbook_of_Research_on_K-

12_Online_and_Blended_Learning_Second_Edition_/6686813

Barbour, M. K. (2019). The landscape of K-12 online learning: Examining what is known. In M. G. Moore \& W. C. Diehl (Eds.), Handbook of distance education ( ${ }^{\text {th }}$ ed.) (pp. 521-542). New York: Routledge.

Barbour, M. K., \& Kennedy, K. (2014). K-12 online learning: A worldwide perspective. In A. Hirumi (Ed.), Grounded designs for online and hybrid learning: Trends and technologies (pp. 53-74). Washington, DC: International Society for Technology in Education.

Barbour, M. K., Mann, B., \& Melchoir, S. (2018). CASTLE Brief No. 2 - A virtual shortfall: How full-time online learning models are not living up to the promise. Denver, CO: University Council for Educational Administration's Center for the Advanced Study of Technology Leadership in Education. Retrieved from https://static1.squarespace.com/static/528fd1d3e4b023ca755e1561/t/5c51dfe340ec9aeb4 1f03940/1548869604563/2018+-+CASTLE+Brief+02+-+Barbour+Mann+Melchior.pdf

Barbour, M. K., \& Reeves, T. C. (2009). The reality of virtual schools: A review of the literature. Computers and Education, 52(2), 402-416.

Bedeian, A. G. (2004). The gift of professional maturity. Academy of Management Learning and Education, 3(1), 92-98.

Bianchi, W. (2002). The Wisconsin School of the Air: Success story with implications. Educational Technology \& Society, 5(1), 141-147. Retrieved from http://www.ifets.info/journals/5_1/bianchi.html

Misbehaving Toddler or Moody Teenager: Examining the Maturity of the Field of K-12 Online Learning. Michael K. Barbour. 
Borup, J. (2016a). Teacher perceptions of parental engagement at a cyber high school. Journal of Research on Technology in Education, 48(2), 67-83.

Borup, J. (2016b). Teacher perceptions of peer engagement at an online high school. International Review of Research in Open and Distance Learning, 17(3), 231-250. Retrieved from http://www.irrodl.org/index.php/irrodl/article/view/2361

Borup, J. \& Archambault, L. (2019). A time For reflection: Recognizing successes and planning for improvements. Journal of Online Learning Research, 5(2), 119-122. Retrieved from https://www.learntechlib.org/primary/p/210449/

Borup, J., Graham, C. R., \& Drysdale, J. (2014). The nature of online teacher engagement an online high school. British Journal of Educational Technology, 45, 793-806.

Borup, J. \& Stevens, M. (2016). Parents' perceptions of teacher support at a cyber charter high school. Journal of Online Learning Research, 2(1), 3-22. Retrieved from https://www.editlib.org/p/171462

Borup, J., Stevens, M., \& Hasler Waters, L. (2015). Student and parent perceptions of parental engagement at an online charter high school. Online Learning, 19(5). Retrieved from http://olj.onlinelearningconsortium.org/index.php/olj/article/download/699/182

Borup, J., West, R. E., Graham, C. R., \& Davies, R. S. (2014). The adolescent community of engagement: A framework for research on adolescent online learning. Journal of Technology and Teacher Education, 22(1), 107-129.

Bramble, W. J. (1988, Winter). Distance learning in Alaska's rural schools. Learning Tomorrow, 4, 241-256. (ERIC Document Reproduction Service No. ED 302 210)

Broady, K. O., Platt, E. T., \& Bell, M. D. (1931). Practical procedures for enriching the curriculums of small schools. Lincoln, NE: University of Nebraska.

Brown, J. D. (1996). Testing in language programs. Upper Saddle River, NJ: Prentice Hall Regents.

Cavanaugh, C., Barbour, M. K., \& Clark, T. (2009). Research and practice in K-12 online learning: A review of open access literature. International Review of Research in Open and Distance Learning, 10(1). Retrieved from http://www.irrodl.org/index.php/irrodl/article/view/607

Cavanaugh, C. \& Roe, M. (2019). Developing pedagogy and course design skills in novice virtual school teachers in Australia. Journal of Online Learning Research, 5(1), 5-22. Retrieved from https://www.learntechlib.org/primary/p/182244/

Clark, T. (2000). Virtual high schools: State of the states - A study of virtual high school planning and preparation in the United States. Center for the Application of Information Technologies, Western Illinois University.

Clark, T. (2003). Virtual and distance education in American schools. In M. G. Moore, \& W. G. Anderson (Ed.), Handbook of distance education (pp. 673-699). Mahwah, NJ Lawrence Erlbaum Associates, Inc.

Misbehaving Toddler or Moody Teenager: Examining the Maturity of the Field of K-12 Online Learning. Michael K. Barbour. 
Clark, T. (2007). Virtual and distance education in North American schools. In M. G. Moore (Ed.), Handbook of distance education ( $2^{\text {nd }}$ ed.). Mahwah, NJ: Lawrence Erlbaum Associates Inc.

Clark, T. (2013). The evolution of K-12 distance education and virtual schools. In M. G. Moore (Ed.), Handbook of distance education ( $3^{\text {rd }}$ ed., pp. 555-573). New York: Routledge.

Clark, T., \& Barbour, M. K. (2015). Online and distance education in schools: Global perspectives on policy and practice. Sterling, VA: Stylus Publishing.

Coffield, F., Moseley, D., Hall, E., \& Ecclestone, K. (2004). Learning styles and pedagogy in post-16 learning. A systematic and critical review. London: Learning and Skills Research Centre.

Cronbach, L. J., \& Meehl, P. E. (1955). Construct validity in psychological tests. Psychological bulletin, 52(4), 281-302.

Darrow, R. (2010). A comparative study between online charter high schools and traditional high schools in California. Unpublished doctoral dissertation, California State University, Fresno, CA.

DiPietro, M., Ferdig, R. E., Black, E. W. \& Preston, M. (2008). Best practices in teaching K-12 online: Lessons learned from Michigan Virtual School teachers. Journal of Interactive Online Learning, 7(1). Retrieved from http://www.ncolr.org/jiol/issues/getfile.cfm?volID=7\&IssueID=22\&ArticleID=113

Dikkers, A. G., Whiteside, A. L., \& Lewis, S. (2013). Virtual high school teacher and student reactions to the social presence model. Journal of Interactive Online Learning, 12(3), 156-170.

Ellis, K. (2008). Cyber charter schools: Evolution, issues, and opportunities in funding and localized oversight. Educational Horizons, 86(3), 142-152.

Ferdig, R. E., \& Kennedy, K. (Eds). (2014). Handbook of research on K-12 online and blended learning ( $1^{\text {st }}$ ed.). Pittsburgh, PA: Entertainment Technology Center Press, Carnegie Mellon University. Retrieved from https://figshare.com/articles/Handbook_of_Research_on_K12_Online_and_Blended_Learning/6686810

Friend, B., \& Johnston, S. (2005). Florida Virtual School: A choice for all students. In Z. L. Berge \& T. Clark (Eds.), Virtual schools: Planning for success (pp. 97-117). New York: Teachers College Press.

Geelan, D. (2006). Undead theories: Constructivism, eclecticism and research in education. Rotterdam, The Netherlands: Sense Publishers.

Graham, C. R., Henrie, C. R., \& Gibbons, A. S. (2014). Developing models and theory for blended learning research. In A. G. Picciano, C. D. Dziuban, \& C. R. Graham (Eds.), Blended learning: Research perspectives (Vol. 4, pp.13-33). New York: Routledge.

Misbehaving Toddler or Moody Teenager: Examining the Maturity of the Field of K-12 Online Learning. Michael K. Barbour. 
Hasler Waters, L., Barbour, M. K., \& Menchaca, M. P. (2014). The nature of online charter schools: Evolution and emerging concerns. Journal of Educational Technology \& Society, 17(4), 379-389. Retrieved from https://www.j-ets.net/ETS/journals/17_4/26.pdf

Hezel Associates. (1998). Educational telecommunications and distance learning: The state-bystate analysis, 1998-99. Syracuse, NY: Hezel Associates.

Holloway, R. E. (1996). Diffusion and adoption of educational technology: A critique of research design. In D. Jonassen (Ed.). Handbook of research on educational communications and technology ( ${ }^{\text {st }}$ ed.) (pp. 1107-1133). New York: Simon \& Schuster Macmillian.

Howley, C. B., \& Harmon, H. L. (2000). K-12 unit schooling in rural America: A first description. Rural Educator, 22(1), 10-18.

Hu, M., Arnesen, K., Barbour, M.K. \& Leary, H. (2019). A newcomer's lens: A look at K-12 online and blended learning in the Journal of Online Learning Research. Journal of Online Learning Research, 5(2), 123-144. Retrieved from https://www.learntechlib.org/primary/p/195231/

International Association for K-12 Online Learning. (2011). The online learning definitions project. Vienna, VA: Author. Retrieved from http://www.inacol.org/wpcontent/uploads/2015/02/iNACOL_DefinitionsProject.pdf

International Association for K-12 Online Learning. (2011). The history of iNACOL. Vienna, VA: Author. Retrieved from https://web.archive.org/web/20150311194547/http://www.inacol.org/history-of-inacol/

Jajkowski, S. (2004). MPATI: The flying classroom. Chicago, IL: Chicago Television. Retrieved from http://www.chicagotelevision.com/MPATI.htm

Januszewski, A., \& Molenda, M. (Eds.). (2008). Educational technology: A definition with commentary. New York: Lawrence Erlbaum Associates.

Kennedy, K., \& Ferdig, R. (2018). Handbook of research on K-12 online and blended learning $\left(2^{\text {nd }} e d\right)$. Pittsburgh, PA: ETC Press. Retrieved from https://figshare.com/articles/Handbook_of_Research_on_K12_Online_and_Blended_Learning_Second_Edition_/6686813

Kirby, E. (1998). Administrative issues for high school distance education. Online Journal of Distance Learning Administration, 1(2). Retrieved from https://www.westga.edu/ distance/ojdla/summer12/kirby12.html

Klein, C., \& Poplin, M. (2008). Families home schooling in a virtual charter school system. Marriage \& Family Review, 43(3-4), 369-395.

Kuhn T. S. (1970). The structure of scientific revolutions ( $2^{\text {nd }}$ ed.). Chicago, IL: The University of Chicago Press.

Kurtz, B. E. (1959). Pioneering in educational television, 1932-1939. Iowa City, IA: State University of Iowa.

Misbehaving Toddler or Moody Teenager: Examining the Maturity of the Field of K-12 Online Learning. Michael K. Barbour. 
Lincoln, Y.S., and Lynham, S.A., (2011). Criteria for assessing theory in human resource development from an interpretive perspective. Human Resource Development International, 14(1), 3-22.

Liu, F., Black, E., Algina, J., Cavanaugh, C., \& Dawson, K. (2010). The validation of one parental involvement measurement in virtual schooling. Journal of Interactive Online Learning, 9(2). Retrieved from http://www.ncolr.org/jiol/issues/pdf/9.2.2.pdf

Lokey-Vega, A., Jorrín-Abellán, I. M., \& Pourreau, L. (2018). Theoretical perspectives in K-12 online learning. In K. Kennedy \& R. Ferdig (Eds.), Handbook of research on K-12 online and blended learning (2nd ed.) (pp. 65-90). Pittsburgh, PA: ETC Press. Retrieved from https://figshare.com/articles/Handbook_of_Research_on_K12_Online_and_Blended_Learning_Second_Edition_/6686813

Lowes, S. (2014). A brief look at the methodologies used in the research on online teaching and learning. In R. Ferdig \& K. Kennedy (Eds.), Handbook of research on K-12 online and blended learning (pp. 83-104). Pittsburgh, PA: ETC Press. Retrieved from https://figshare.com/articles/Handbook_of_Research_on_K12_Online_and_Blended_Learning/6686810

Lowes, S., \& Lin, P. (2018). A brief look at the methodologies used in the research on online teaching and learning. In K. Kennedy \& R. Ferdig (Eds.), Handbook of research on K-12 online and blended learning (2nd ed.) (pp. 91-110). ETC Press. Retrieved from https://figshare.com/articles/Handbook_of_Research_on_K12_Online_and_Blended_Learning_Second_Edition_/6686813

Mann, B., Kotok, S., Frankenberg, E., Fuller, E., \& Schafft, K. (2016). Choice, cyber charter schools, and the educational marketplace for rural school districts. The Rural Educator, 37(3). Retrieved from

Miron, G., \& Gulosino, C. (2016). Virtual schools report 2016: Directory and performance review. Boulder, CO: National Education Policy Center. Retrieved from http://nepc.colorado.edu/publication/virtual-schools-annual-2016

Miron, G., Shank, C. \& Davidson, C. (2018). Full-time virtual and blended schools: Enrollment, student characteristics, and performance. Boulder, CO: National Education Policy Center. Retrieved from http://nepc.colorado.edu/publication/virtual-schools-annual-2018

Miron, G., \& Urschel, J. (2012). Understanding and improving full-time virtual schools. Boulder, CO: National Education Policy Center. Retrieved from http://nepc.colorado.edu/publication/understanding-improving-virtual

Molnar, A. (Ed.); Huerta, L., Barbour, M. K., Miron, G., Shafer, S. R., Gulosino, C. (2015). Virtual schools in the U.S. 2015: Politics, performance, policy, and research evidence. Boulder, CO: National Education Policy Center. Retrieved from http://nepc.colorado.edu/publication/virtual-schools-annual-2015

Molnar, A., Miron, G., Huerta, L., Cuban, L., Horvitz, B., Gulosino, C., Rice, J. K., \& Shafer, S. R. (2013). Virtual schools in the U.S. 2013: Politics, performance, policy, and research

Misbehaving Toddler or Moody Teenager: Examining the Maturity of the Field of K-12 Online Learning. Michael K. Barbour. 
evidence. Boulder, CO: National Education Policy Center. Retrieved from http://nepc.colorado.edu/publication/virtual-schools-annual-2013

Molnar, A. (Ed.); Miron, G., Gulosino, C., Shank, C., Davidson, C., Barbour, M. K., Huerta, L., Shafter, S. R., Rice, J. K., \& Nitkin, D. (2017). Virtual schools in the U.S. 2017. Boulder, CO: National Education Policy Center. Retrieved from http://nepc.colorado.edu/publication/virtual-schools-annual-2017

Molnar, A. (Ed.); Rice, J. K., Huerta, L., Shafer, S. R., Barbour, M. K., Miron, G., Gulosino, C., \& Horvitz, B. (2014). Virtual schools in the U.S. 2014: Politics, performance, policy, and research evidence. Boulder, CO: National Education Policy Center. Retrieved from http://nepc.colorado.edu/publication/virtual-schools-annual-2014

Pape, L., Adams, R., \& Ribeiro, C. (2005). The Virtual High School: Collaboration and online professional development. In Z. L. Berge \& T. Clark (Eds.), Virtual schools: Planning for success (pp. 118-132). New York: Teachers College Press.

Pease, P. S., \& Tinsley, P. J. (1986, October 7-10). Reaching rural schools using an interactive satellite based educational network. Paper presented at the Annual Conference of the National Rural and Small Schools Consortium, Bellingham, WA. (ERIC Document Reproduction Service No. ED 281 681).

Rice, K. L. (2006). A comprehensive look at distance education in the K-12 context. Journal of Research on Technology in Education, 38(4), 425-448.

Rice, M., Oritz, K., Curry, T. \& Petropoulos, R. (2019). A case study of a foster parent working to support a child with multiple disabilities in a full-time virtual school. Journal of Online Learning Research, 5(2), 145-168. Retrieved from https://www.learntechlib.org/primary/p/184933/

Roblyer, M. D. (2005). Who plays well in the virtual sandbox? Characteristics of successful online students and teachers. SIGTel Bulletin, (2). Retrieved from http://web.archive.org/web/20060930130650/http://www.iste.org/Content/NavigationMe nu/Membership/SIGs/SIGTel_Telelearning_/SIGTel_Bulletin2/Archive/2005_20067/200 5_July_-_Roblyer.htm

Roblyer, M. D. (2006). Virtually successful: Defeating the dropout problem through online school programs. Phi Delta Kappan. 88(1), 31-36.

Roblyer, M. D., \& Davis, L. (2008). Predicting success for virtual school students: Putting research-based models into practice. Online Journal of Distance Learning

Administration, 11(4). Retrieved from https://www.westga.edu/ distance/ojdla/winter114/roblyer114.html

Roblyer, M. D., Davis, L., Mills, S. C., Marshall, J., \& Pape, L. (2008) Toward practical procedures for predicting and promoting success in virtual school students. American Journal of Distance Education, 22(2), 90-109.

Misbehaving Toddler or Moody Teenager: Examining the Maturity of the Field of K-12 Online Learning. Michael K. Barbour. 
Roblyer, M. D., \& Marshall, J. C. (2002-2003). Predicting success of virtual high school students: Preliminary results from an educational success prediction instrument. Journal of Research on Technology in Education, 35(2), 241-255.

Saba, F. (2003). Distance education theory, methodology, and epistemology: A pragmatic paradigm. In M. G. Moore (Ed.), Handbook of distance education (1 ${ }^{\text {st }}$ ed.) (pp. 3-20). Mahwah, NJ: Lawrence Erlbaum Associates, Publishers.

Saba, F. (2007). A systems approach in theory building. In M. G. Moore (Ed.), Handbook of distance education (2 ${ }^{\text {nd }}$ ed.) (pp. 43-55). Mahwah, NJ: Lawrence Erlbaum Associates, Publishers.

Saba, F. (2013). Building the future: A theoretical perspective. In M. G. Moore (Ed.), Handbook of distance education ( $3^{\text {rd }}$ ed.) (pp. 49-65). New York: Routledge.

Saettler, L. P. (2004). The evolution of American educational technology. Charlotte, NC: Information Age Publishing

Scott, C. (2010). The enduring appeal of 'learning styles'. Australian Journal of Education, 54(1), 5-17.

Seok, S. \& DaCosta, B. (2020). Relationships between young South Koreans' online activities and their risk of exploitation. Journal of Online Learning Research, 6(1), 77-101. Retrieved from https://www.learntechlib.org/primary/p/210321/

Siko, J. P. (2014). Testing the waters: An analysis of the student and parent experience in a secondary school's first blended course offering. International Journal of E-Learning \& Distance Education, 29(2). Retrieved from http://www.ijede.ca/index.php/jde/article/download/882/1562/0

Sparks, L. M. (2017). Educational success prediction instrument 2nd version: A foreign language perspective on readiness to take a beginner high school foreign language online course. Unpublished Ed.D. dissertation, Piedmont College, Demorest, GA.

Spector, M. J. (2008). Theoretical foundations. In D. Jonassen, M. J. Spector, M. Driscoll, M. D. Merrill, J. van Merrienboer, \& M. P. Driscoll (Eds.). Handbook of research on educational communications and technology ( $3^{\text {rd }}$ ed.) (pp. 21-28). New York: Lawrence Erlbaum Associates.

Torre, D. (2013). Virtual charter schools: Realities and unknowns. International Journal of ELearning \& Distance Education, 27(1). Retrieved from http://ijede.ca/index.php/jde/article/view/838/1498

Turley, C. \& Graham, C. (2019). Interaction, student satisfaction, and teacher time investment in online high school courses. Journal of Online Learning Research, 5(2), 169-198. Retrieved from https://www.learntechlib.org/primary/p/209812/

Watson, J., \& Murrin, A. (2014). A history of K-12 online and blended instruction in the United States. In R. E. Ferdig \& K. Kennedy (Eds.), Handbook of Research on K-12 Online and Blended Learning (pp. 1-24). Pittsburgh, PA: Entertainment Technology Center Press, Carnegie Mellon University.

Misbehaving Toddler or Moody Teenager: Examining the Maturity of the Field of K-12 Online Learning. Michael K. Barbour. 
RED. Revista de Educación a Distancia. Núm. 64, Vol. 20. Artíc. 4, 30-09-2020

Whiteside, A. L., \& Dikkers, A. G. (2012). Maximizing multicultural online learning experiences with the social presence model, course examples, and specific strategies. In K. St. Amant \& S. Kelsey (Eds.), Computer-mediated communication across cultures: International interactions in online environments (pp. 395-413). Hershey, PA: IGI Global. 